\title{
An Exploration of Recursive Conversations and Learner Performance
}

\section{David S. Bowyer \\ Nagoya Gakuin University}

\section{Reference Data}

Bowyer, D. S. (2020). An exploration of recursive conversations and learner performance. In P. Clements, A. Krause, \& R. Gentry (Eds.), Teacher efficacy, learner agency. Tokyo: JALT. https://doi.org/10.37546/JALTPCP2019-29

According to complex dynamic systems theory (CDST), L2 learning is a nonlinear process in which learners' language systems are always changing and iterating through interactions with which learners' language systems are always changing and iterating through interactions with
the learning environment (Larsen-Freeman, 2019). Recursive conversations (RCs) are a type of classroom practice that was developed from CDST, providing learners with iterative conversation practice and reflection opportunities (Kindt, 2004). Research published by Bowyer (2019) showed that learners believed that RCs enabled them to achieve increased performance in conversation. This present study is an attempt to explore this belief by examining the performance of four selected learners and to explain the changes through a detailed account of their experiences. A mixed methods exploratory-explanatory approach, utilizing quantitative performance analysis of transcribed conversations and qualitative interviews, was used. Results showed that learners' fluency and interactional competence improved, but accuracy was largely unaffected. Furthermore, speaking partners and feedback quality were significant factors.

複雑性ダイナミック・システム理論 (CDST) によると、第2言語学習は学習者の言語システムが学習環境とともにある反復的 会話活動を通して常に変化し、進化し続ける過程である(ラーセンフリーマン、2019年)。反復的言語活動 (RCs) はCDSTを利用 するための教室活動の一種であり、学習者に反復的会話練習と内省の機会を与える(キント、2004年)。ボイヤー(2019年)に よると、学習者たちはRCsが会話におけるパフォーマンス向上に役立つと信じている。本研究では、4人の学習者のパフォーマ ンスに注目することで彼らのRCsを通しての学習経験によって起きた変化の説明をする事を目的とし、テキストに変換された 会話の量的分析とインタビューにおける質的分析を基とした混合型探究及び説明的調査を試みた。結果として、学習者の流 暢さと相互行為能力が向上したが、正確さに関しては影響が見られなかった。しかしながら、会話活動のパートナーとフィード バックの質が重要な要因を担っていることが示された omplex dynamic systems theory (CDST) dictates that language learning is a

nonlinear process in which learners' L2 systems are constantly changing through the interaction between learners and their environment (Larsen-Freeman, 2009, p. 585). By its nature, $\mathrm{L} 2$ acquisition is a personal process and can benefit from individualized approaches to teaching that focus on providing learners with the tools to take control of the process (Earl, 2013, p. 31). Recursive conversations (RCs), based upon CDST, may be beneficial in aiding learners to become more proficient in L2 spoken interactions (Kindt \& Bowyer, 2018) and in developing positive learning beliefs (Bowyer, 2019).

This mixed methods research builds on previous qualitative research (Bowyer, 2019), which showed that learners believed that RCs helped them to achieve increased L2 interactional competence, by comparing the learners' stated beliefs with quantitative performance data from their interactions. An exploratory research design (see Creswell, Plano Clark, Gutman \& Hanson, 2003), using quantitative data from recorded RCs and the author's written class notes, was employed with selected learners during their first semester at a Japanese university. A discussion of the results and their implications is followed by a conclusion of the key issues and limitations of this present study.

\section{Literature Review}

Interactional Competence

Since Canale and Swain (1980) began a revolution in language education with their explanation of communicative competence in $\mathrm{L} 2$ acquisition, the teaching of communication strategies (CSs) has become a cornerstone of many curriculums.

However, as Young (2011), coming from a sociocultural theory standpoint, has argued, the original CSs were narrow in scope and focused only on fixing communication breakdowns. By expanding on Canale and Swain's definition of key competencies, Young produced a more robust and holistic set of CSs, which he termed "interactional competence" (IC; p. 429). As Brown (2014) explained, from an IC perspective, learners 
must be provided with not only the $\mathrm{L} 2$ knowledge necessary for interaction, but also the experience of using the $\mathrm{L} 2$ successfully in context (p. 216).

\section{Recursive Conversations}

Since the 1990s, Larsen-Freeman has been researching and publishing on the applications of CDST to language learning (Larsen-Freeman, 1997). However, only relatively recently have her ideas come to be discussed in the wider $\mathrm{L} 2$ research community, such as in Atkinson's (2019) discussion of transdisciplinary research practices. CDST holds that learners' $\mathrm{L} 2$ systems are dynamic and complex, meaning that they iterate over time through repeated similar L2 experiences (Larsen-Freeman, 2009). $\mathrm{RCs}$ are an application of CDST intended to take account of this iterative aspect of $\mathrm{L} 2$ development, by providing learners with ample opportunities to experience, reflect, and re-experience L2 communication, as depicted in Figure 1.

\section{Conversation 1}

\section{Feedback}

\section{Conversation 2}

\section{Feedback}

\section{Conversation 3}

\section{Feedback}

Figure 1. The RCs process.

According to Kindt, recursion promotes the developmental restructuring of learners' interlinguistic systems through the "return to a similar experience-but with a wider knowledge" (2004, p. 15). Recursion typically involves "listening to/watching language production, doing follow-up activities, focusing on forms, self-evaluating, receiving peer evaluation ... within slightly different contexts" (Kindt, 2005, p. 176). By reviewing and revisiting L2 experiences, learners can "reveal, construct, [and] restructure" their L2 knowledge (Murphey, 2001, p. 143). Through this process, it is theorized that L2 learners may be able to achieve increased IC. Typically, RCs involve multiple interlinked stages of conversation and reflection, but the specific types of conversation and reflection are not set and should be adapted in order to suit the learners. For example, in this study learners engaged in three 7-minute three-person conversations, each time with new partners. Between each conversation the learners received oral feedback from a tutor, and they also kept a personal journal that they completed at the beginning and end of class.

However, a more practical procedure could simply involve repeated pair conversations, with between-conversation reflection periods in which learners keep a journal of their usage of particular target language.

\section{Research Questions}

In their 2018 article, Kindt and Bowyer's initial research on RCs showed that learners considered RCs to be more interesting and less challenging in comparison to single conversations. A follow-up pilot study with a new set of participants found that RCs led to the development of the following three beliefs among learners: (a) RCs aid in the learning of L2 vocabulary, phrases, and strategies; (b) L2 speaking performance increases during RCs; and (c) RCs lead to improved L2 speaking proficiency (Bowyer, 2019). This present study is intended to explore the second belief, namely that $\mathrm{L} 2$ performance increases during RCs. In order to do this, the following research questions (RQs) were developed:

RQ1. How do RCs affect spoken fluency?

RQ2. How do RCs affect interactional complexity?

RQ3. How do RCs affect accuracy?

RQ4. What factors affect learner performance during RCs?

\section{Method}

\section{Participants}

This study was conducted at a Japanese university with a cohort of 48 first-year English education majors during the first semester of a weekly, 45-minute, English oral communication course. The cohort was divided into two classes of 24 learners, with each class being taught by eight native English speakers, including the author. Based on a combination of (a) their answers in a written consent form, which all students completed, and (b) performance in a rubric-assessed (Appendix A) speaking test, four student learners (SLs) were chosen based on Larsen-Freeman (2006). In order to ensure 
richness and variety in the answers that they would be able to provide, learners were also selected based on gender and relative oral proficiency (Dörnyei, 2007, p. 216). The four SLs were designated as the following: female-low (Saori), female-high (Ayana), male-low (Riki) and male-high (Ryuichi). The provided names are pseudonyms in order to maintain anonymity.

\section{Procedure}

The two classes were divided randomly into groups of three learners, each with an assigned teacher. From the second week onwards, each class began with students and teachers in their home groups. The selected learners were put into separate home groups for ease of data collection. Classes were conducted in the same fashion every week,

beginning with a 10-minute training session on one of the CSs in the textbook (Appendix B). In Week 2, which is the main focus of this article, the training centered on asking a partner for help using English (Appendix C). Following this, learners engaged in three 7-minute, three-person group RCs with different partners, for which they had prepared self-help notes as part of their homework. Between each conversation, teachers provided feedback based on the rubric.

This study was conducted using a mixed methods exploratory design, employing qualitative interviews and quantitative performance data (Creswell et al., 2003, p. 220). A previous article (Bowyer, 2019) discussed the results of the study with regard to learners' beliefs. This paper will explore the results of the performance data in light of the learners' stated beliefs about the effects of RCs.

The selected learners were video recorded during the second week, which was also their first experience with RCs. Their RCs were transcribed, then analyzed for (a) fluency, (b) IC, and (c) accuracy because the SLs' interview answers indicated that they felt that RCs improved their spoken performance (Bowyer, 2019). These three areas also provide a broad, multifaceted description of learner speaking competency (Ellis \& Barkhuizen 2016). Each area was calculated using the single factor that has been shown to be the strongest predictor of performance in that area. These factors are (a) syllables per minute (SPM) for fluency, (b) turns per minute (TPM) for interactional complexity, and (c) the percentage of error-free clauses (\%EFC) in the case of accuracy (pp. 139-158). As the sample is too small for the use of inferential statistics, only descriptive statistics were used (Brown, 2014, p. 41).
Qualitative semistructured interviews (see Appendix D) were conducted by the author with the SLs in Japanese, having first been piloted with a professional peer and a former student. Interviews were then transcribed and coded in order to provide avenues of inquiry for the quantitative part of the research. Although six interviewees are typically considered ideal in qualitative research, in this case a smaller number was chosen (see Dörnyei, 2007, p. 127). Echoing Larsen-Freeman (2006), the interviews were not required for producing a thick description, but rather for creating areas of examination for the quantitative data collection and explaining the results. The data from these interviews, published in Bowyer (2019), were also used to add depth and context to the quantitative findings and to examine the factors affecting learner performance.

\section{Results and Discussion}

The following section displays the quantitative data regarding SLs' performance in the RCs. I also discuss the implications of these results for RQ1 to RQ3. Qualitative data was compared with the quantitative results in a mixing stage in order to provide some explanation of why the performance results appear as they do.

\section{RQ1: How Do RCs Affect Spoken Fluency Performance?}

The summarized fluency data from all of the SLs' transcribed RCs can be seen in Table 1. Each of the SLs' fluency scores were calculated for each phase of the RCs by dividing the total number of syllables by the speaking time in minutes. The mean fluency shows a steady increase from 26 SPM in Conversation 1, to 28 and 31 in Conversations 2 and 3 , respectively. From Conversation 1 to Conversation 2, this represents a total change of $+19 \%$. 
Table 1. SLs Fluency Scores (SPM)

\begin{tabular}{lccc}
\hline & \multicolumn{3}{c}{ Conversation } \\
\hline Learner & 1 & 2 & 3 \\
Saori & 13 & 11 & 16 \\
Ryuji & 16 & 28 & 16 \\
Ayana & 44 & 47 & 55 \\
Riki & 30 & 27 & 37 \\
\hline Mean & 26 & 28 & 31 \\
\hline$S D$ & 12 & 13 & 16 \\
\hline
\end{tabular}

Note. $\mathrm{SL}=$ Student learner. $\mathrm{SPM}=$ syllables per minute.

Individually, the SLs show considerable variation both in their beginning SPM and their changes. Saori begins at 13 SPM, decreases to 11 SPM in Conversation 2, then increases to 16 SPM in Conversation 3. Riki displays the same pattern, but his SPM is generally triple that of Saori. Ayana displays a steady increase from 44 SPM in Conversation 1 up to 55 SPM in Conversation 3. Ryuji's experience is somewhat different from the others, as he shows the same score of 16 SPM in Conversations 1 and 3, with a peak of 28 SPM in Conversation 2. Taken together, it can be seen that the RCs had a strong, but not uniform, effect on the SLs' fluency, with three of the four displaying peak SPM in Conversation 3.

The $19 \%$ increase in mean fluency scores over three conversations seems quite high, particularly considering the fact that RCs have a broad interactional competency focus. As the learners moved from one conversation to the next, they became more comfortable with the topic and were able to share more information in the same amount of time. In classrooms where increased spoken L2 fluency is a desired outcome, RCs may be an appropriate technique based on these results. However, as is also clear from Ryuji's scores, individual differences can have a large impact on performance and may therefore be a consideration for educators when implementing RCs in their own classroom.

\section{RQ2: How Do RCs Affect Spoken IC Performance?}

To calculate spoken interactional complexity, the SLs' transcribed RCs were analyzed for the average number of TPM, as displayed in Table 2. Beginning with the mean score, we see an increase from 8.1 TPM in Conversation 1, to 8.3 in Conversation 2. This is followed by another increase to 8.9 TPM in Conversation 3, representing a total change of $+10 \%$.

Table 2. SLs Complexity Scores (TPM)

\begin{tabular}{lccc}
\hline & \multicolumn{3}{c}{ Conversation } \\
\hline Learner & 1 & 2 & 3 \\
Saori & 4.4 & 5.6 & 5.6 \\
Ryuji & 6.4 & 8.2 & 7.6 \\
Ayana & 11.0 & 9.7 & 13.2 \\
Riki & 10.7 & 9.8 & 9.3 \\
\hline Mean & 8.1 & 8.3 & 8.9 \\
\hline$S D$ & 2.8 & 1.7 & 2.8 \\
\hline
\end{tabular}

Note. $\mathrm{SL}=$ Student learner. $\mathrm{TPM}=$ turns per minute.

Although the mean results show a progression from less to more complexity, the results of the individual SLs are less predictable. Saori's results are the closest to a clean progression, increasing from 4.4 TPM in Conversation 1, to 5.6 TPM in Conversations 2 and 3. Ryuji's complexity scores display a similar pattern to his fluency scores, peaking in the second conversation at 8.2 TPM. Ayana's complexity decreases from 11 TPM in Conversation 1 to 9.7 TPM in Conversation 2 then increases to its highest level of 13.2 in Conversation 3. Riki's data lie in contrast to the mean scores, decreasing from its maximum of 10.7 TPM in Conversation 1 to 9.8 TPM and 9.3 TPM in Conversations 2 and 3.

Although the individual results show considerable variation, when taken together a pattern of increasing complexity can be seen as learners move through the RCs, with an increase in mean TPM of 10\%. Given the increased fluency score, it is perhaps not surprising that learners' turn counts also increased. Getting through the same amount of information more quickly would necessarily lead to free time at the end of the conversation for more speech and more turns, which the learners seem to have made use of. 


\section{RQ3: How Do RCs Affect Spoken Accuracy Performance?}

The accuracy scores for each learner and the mean percentage of error-free clauses, in $\% E F C$, are shown in Table 3. First considering the mean, it can be seen that accuracy decreases slightly from $57 \% \mathrm{EFC}$ in conversation one, to $56 \% \mathrm{EFC}$ in conversation two, then increases to $58 \% \mathrm{EFC}$ in conversation three. Proportionately, this represents a total change in accuracy of $+4 \%$.

Table 3. SLs Accuracy Scores (\%EFC)

\begin{tabular}{lccc}
\hline & \multicolumn{3}{c}{ Conversation } \\
\hline Learner & 1 & 2 & 3 \\
Saori & 50 & 55 & 54 \\
Ryuji & 55 & 46 & 67 \\
Ayana & 71 & 53 & 50 \\
Riki & 52 & 70 & 63 \\
& & & 58 \\
\hline Mean & 57 & 56 & 7 \\
\hline$S D$ & 8 & 9 & \\
\hline
\end{tabular}

Note. $\mathrm{SL}=$ Student learner. $\mathrm{EFC}=$ error-free clause.

Looking at the individual scores, considerable variation in accuracy changes can be seen between the SLs. Saori improves from 50\%EFC in Conversation 1 to 55\%EFC in Conversation 2 then remains almost unchanged at 54\%EFC in Conversation 3. Ryuji's score decreases from 55\%EFC in Conversation 1 to $46 \% \mathrm{EFC}$ in Conversation 2 before increasing to $67 \% \mathrm{EFC}$ in Conversation 3. Ayana's accuracy was at its highest in Conversation 1, at 71\%EFC, before dropping to 53\%EFC in Conversation 2 and again to $50 \% \mathrm{EFC}$ in the third conversation. Riki's accuracy increases from $52 \% \mathrm{EFC}$ in Conversation 1 to $70 \% \mathrm{EFC}$ in Conversation 2 then drops to 63\% EFC in the third.

Examining the scores individually seems to show little pattern regarding accuracy changes, although the $+4 \%$ mean change shows that as a group, there was a small improvement in accuracy. Individual differences seem to have had a strong effect on spoken accuracy, making it difficult to evaluate whether RCs had any effect. Given the variation in scores and peak accuracy performance and the relatively small change in the mean score, RCs had either a very small or no impact upon learner accuracy. A larger study utilizing statistical analysis might clarify the issue but is beyond the scope of this study.

\section{RQ4: What Factors Affect Learner Performance During RCs?}

As evidenced by the differing patterns of change in fluency, IC, and accuracy displayed by the SLs, there are likely several factors that can influence performance during RCs. Saori's scores showed increases in all three measured areas through the RCs, with fluency peaking in Conversation 3, and IC and accuracy plateauing after Conversation 2. Ryuji's scores indicated high peaks in fluency and IC during Conversation two, accompanied by reduced accuracy in the same conversation. Ayana's fluency and IC scores increased steadily, while her accuracy score decreased. Riki's fluency and accuracy scores both increased, while his IC score decreased steadily.

The set of scores that most stood out to the author were Ryuji's, due to the large performance peak in Conversation 2. In personal communication with the other course teachers, it came to light that his best friend was one of the group members in Conversation 2. A large increase in the amount spoken, accompanied by a concurrent decrease in accuracy, seems to be exactly the kind of change that one might expect to see in a learner who is in the presence of a partner with whom they feel secure and able to speak freely. Although Ryuji's example is particularly powerful, it seems likely that group composition did not affect only him and may well be a significant factor in learner performance.

During interviews, the SLs indicated that nervousness could be a factor in their performance due to a desire not to make mistakes in front of others. Riki explained his feelings about Conversation 1 as follows:

Riki： なんか間ができないように皆で会話を続けようって [we're careful not to leave gaps in the conversation]

Scott: $\quad$ ahh(あ一) 最初はちょつと [ahh, at first it's a little]

Riki:＼cjkstart皆ぎこちない感じで

[everybody is nervous] 
Based on Riki's comment, it's clear that some learners experience nervousness in the first conversation. If this is true, one might expect to see a reduction in accuracy as learners become more relaxed and less careful. This is what we see in the case of Ayana, whose accuracy score drops steadily from $71 \% \mathrm{EFC}$ in Conversation 1, to $53 \% \mathrm{EFC}$ and $50 \%$ EFC in Conversations 2 and 3. However, the other three SLs did not match this pattern and actually showed increased accuracy after Conversation 1 . This does not necessarily disprove the SLs' interviews but adds to the notion that performance is a complex process with several things happening at the same time. Although all four SLs may have experienced nervousness, they responded to it in different ways.

The other key factor that became clear during the interview process was the effects of the feedback that the SLs received from tutors. When quizzed on her thoughts regarding feedback, Saori stated the following:

\section{Saori:}

フィードバックえコメントもらって次の部屋に行くときにこの注意を改善できるよう

[after I receive feedback uhh comments then when I go to the next room I try to improve the focus point]

Based on this evidence, it appears likely that learners were using the feedback from their tutors as a way to try to improve their performance in subsequent conversations. This may go some way toward explaining why the accuracy results were inconclusive; the feedback that the SLs received would have been tailored to suit the individual learner, affecting them all in different ways. It may be the case that where learners received feedback that was difficult to implement, their accuracy increased as they focused on the use of specific language areas. Conversely, one would expect to see decreased fluency for the same reason. However, despite learners receiving the majority of feedback between Conversations 2 and 3, the accuracy results are not particularly supportive of an increased focus on accuracy in Conversation 3.

\section{Conclusion}

The performance analysis of the SLs' RCs showed that learners' belief that their performance improves during RCs was largely correct. The SLs' mean performance increased markedly from Conversations 1 to 3, particularly fluency and IC. Although accuracy did improve overall, the effects were very small and possibly overridden by other factors. It is clear from these results that RCs can have a powerful effect on learners' $\mathrm{L} 2$ spoken competence over a short period of time, making them a potentially powerful tool in the classroom. However, for courses in which accuracy is important, it may be necessary to include separate accuracy-focused activities that can support the fluency and IC benefits of the RCs.

As became clear during the answering of RQ4, there are several factors that need to be taken into account when implementing RCs, namely (a) speaking partners, (b) nervousness, and (c) feedback. Partner choice can have a large effect on learner performance, which in this study appeared to be quite positive. However, there is the potential for the opposite to happen, with poorly matched partners leading to poor performance and possibly poor learning as a result. It may be beneficial for educators to consider learners' relationships and to assign RCs groups accordingly.

Possibly related to speaking partners is the issue of learner nervousness, particularly during the first conversation. Although it did not have a particularly strong impact in this study, the fact that the SLs brought it up in interviews indicates that it is a genuine issue. With groups of learners who are less confident in their L2 than the English majors from this research, anxiety may be a significant factor in learners' engagement with the RCs. In these situations, educators may need to consider adjusting the RCs. For example, if 7-minute conversations are too anxiety inducing, perhaps begin with shorter conversations. Beginning conversation one with a familiar partner might also allow learners to relax and engage more effectively.

Lastly, on the issue of feedback and its effects, learners considered the individualized feedback that they received from tutors to be beneficial, and at the very least, it did not show any signs of negatively impacting performance. However, I am aware that most educators do not have an army of tutors to call on for their English conversation classes, and it is simply not practical for one teacher to give personalized performance feedback simultaneously to a whole class of learners. This is currently the case for my own conversation classes. In response to this, I created a simplified L1 rubric that learners could use to observe each other and provide feedback, essentially handing over the tutor role to the learners themselves. This adaptability is one of the key strengths of RCs, allowing them to be used in potentially any $\mathrm{L} 2$ classroom, from elementary school classes to university level, and to have performance benefits in all of them.

\section{Limitations}

The first limitation of this study was related to the scope of the results. As this was an exploratory-explanatory study, only four learners were examined. This had the advantage of allowing for a deeper analysis of the data but did not allow for statistical testing. Consequently, the strength of the conclusion and the applicability of the research to 
other contexts are somewhat limited. Future research should be aimed at examining the effects of RCs on a larger cohort that allows for statistical analysis and the reliability and wider applicability that this can bring.

Although potential relationships between feedback and performance were briefly touched upon, I could not delve deeply into this issue in this study. This area is ripe for more research and might shed more light on how to make the best use of RCs. Another area that was beyond the scope of this paper was what exactly was changing in terms of learner use of specific L2 vocabulary phrases during RCs. A future conversation analysisinformed study would likely provide interesting insights into changing language patterns in real time. Lastly, it should be noted that this study was conducted with English majors, therefore representing the high achievers of L2 study in Japan. Conducting similar research with learners from different backgrounds could lead to quite different and perhaps even more useful insights.

\section{Bio Data}

D. S. Bowyer has been teaching English in Japan for the past 10 years and currently lectures at Nagoya Gakuin University. His research interests include assessment, chaos/ complexity theory and interactional competence. <scottybowyer1@gmail.com>

\section{References}

Amrein, J., Bogedin, C., Bowyer, D. S., Deadman, A., Harris, R. B., Koga, A., ... Walters, J. R. (2017). Power-up dialogue I. Nagoya, Japan: Nagoya University of Foreign Studies Press.

Atkinson, D. (2019). Second language acquisition beyond borders? The Douglas Fir Group searches for transdisciplinary identity. The Modern Language Journal, 103, 113-121. https://doi.org/10.1111/modl.12530

Bowyer, D. S. (2019). Exploring the effects of recursive conversations on L2 learner beliefs. In Krause, A., \& Bennett, P. (Eds.), Diversity and Inclusion. Tokyo, Japan: JALT. https://doi.org/10.37546/JALTPCP2018-20

Brown, J. D. (2014). Mixed methods research for TESOL. Edinburgh, Scotland: Edinburgh University Press.

Canale, M., \& Swain, M. (1980). Theoretical bases of communicative approaches to second language teaching and testing. Applied Linguistics, 1(1), 1-47. https://doi.org/10.1093/applin/l.1.1
Creswell, J. W., Plano Clark, V. L., Gutman, M. L., \& Hanson, W. E. (2003). Advanced mixed methods research designs. In A. Tashakkori \& C. Teddlie (Eds.), Handbook of mixed methods in social \& behavioral research. Thousand Oaks, CA: Sage.

Dörnyei, Z. (2007). Research methods in applied linguistics. Oxford, England: Oxford University Press.

Earl, L. (2013). Assessment as learning (2nd ed.). Thousand Oaks, CA: Corwin.

Ellis, R., \& Barkhuizen, G. (2016). Analysing learner language. Oxford, England: Oxford University Press.

Kindt, D., \& Bowyer, D. S. (2018). A working paper exploring the effects of recursive conversations on participants' fluency development in a first-year EFL oral communication course. Nagoya University of Foreign Studies Ronshu, 2, 103-129.

Larsen-Freeman, D. (1997). Chaos/complexity science and second language acquisition. Applied Linguistics, 18(2), 141-165. https://doi.org/10.1093/applin/18.2.141

Larsen-Freeman, D. (2006). The emergence of complexity, fluency, and accuracy in the oral and written production of five Chinese learners of English. Applied Linguistics, 27(4), 590-619. https://doi.org/10.1093/applin/aml029

Larsen-Freeman, D. (2009). Adjusting expectations: The study of complexity, accuracy, and fluency in second language acquisition. Applied Linguistics, 30(4), 579-589. https://10.1093/applin/amp043

Larsen-Freeman, D. (2019). On language learner agency: A complex dynamic systems theory perspective. The Modern Language Journal, 103, 61-79. https://doi.org/10.1111/modl.12536

Murphey, T. (2001). Tools of recursion, intermental ZPDs \& critical collaborative autonomy. JALT Journal, 23(1), 130-150. https://doi.org/10.37546/JALTJJ23.1-7

Young, R. F. (2011). Interactional competence in language learning, teaching, and testing. In E. Hinkel (Ed.), Handbook of research in second language teaching and learning (Vol. 2, pp. 426-443). New York, NY: Routledge. 


\section{Appendix A}

Feedback and Performance Rubric

\begin{tabular}{|l|l|l|}
\hline Tutor: & Group: & Topic: \\
\hline
\end{tabular}

\begin{tabular}{|c|c|c|c|c|c|}
\hline & 1 & 2 & 3 & Score & Notes \\
\hline Content & $\begin{array}{l}\text { Rarely provides } \\
\text { detail when } \\
\text { speaking. } \\
\text { Description. }\end{array}$ & $\begin{array}{l}\text { Sometimes } \\
\text { provides detail } \\
\text { when speaking. } \\
\text { Description, } \\
\text { preference. }\end{array}$ & $\begin{array}{l}\text { Usually provides } \\
\text { rich informa- } \\
\text { tion. } \\
\text { Description, } \\
\text { preference, } \\
\text { reason. }\end{array}$ & & \\
\hline Participation & $\begin{array}{l}\text { Only partic- } \\
\text { ipates when } \\
\text { asked a ques- } \\
\text { tion; is often } \\
\text { disengaged. }\end{array}$ & $\begin{array}{l}\text { Sometimes } \\
\text { participates } \\
\text { without being } \\
\text { asked a ques- } \\
\text { tion; is usually } \\
\text { engaged. }\end{array}$ & $\begin{array}{l}\text { Interacts/Asks } \\
\text { and answers } \\
\text { questions for } \\
\text { a balanced } \\
\text { conversation; is } \\
\text { always engaged }\end{array}$ & & \\
\hline $\begin{array}{l}\text { Understanda- } \\
\text { bility }\end{array}$ & $\begin{array}{l}\text { Rarely attempts } \\
\text { to understand or } \\
\text { be understood. }\end{array}$ & $\begin{array}{l}\text { Sometimes } \\
\text { attempts to un- } \\
\text { derstand or be } \\
\text { understood, but } \\
\text { may rely on L1. }\end{array}$ & $\begin{array}{l}\text { Usually attempts } \\
\text { to understand or } \\
\text { be understood } \\
\text { without relying } \\
\text { on L1. }\end{array}$ & & \\
\hline & & & Total score: & & \\
\hline
\end{tabular}

\section{Appendix B}

Lesson Procedure

\begin{tabular}{lc}
\hline Activity & Time (min.) \\
\hline Homework check and goal-sharing & 3 \\
Communication skill practice & 10 \\
Conversation 1 & 7 \\
Informal tutor feedback & 1 \\
Change groups & 2 \\
Conversation 2 & 7 \\
Tutor feedback & 3 \\
Change groups & 2 \\
Conversation 3 & 7 \\
Feedback and homework-setting & 3 \\
\hline
\end{tabular}

1. Check Ss' homework and have them share their self-chosen lesson goals as a group.

2. Introduce today's topic and conversation skill. Conduct a short skill-focused activity from the POWER-UP DIALOGUE 1 textbook (Amrein et al., 2017).

3. Have Ss engage in a 7-minute, 3-person group conversation, using their prepared notes. Listen and make notes on any important feedback areas.

4. Provide short informal feedback if required.

5. Two Ss leave the group, and two Ss join.

6. On the same topic as 3, have Ss engage in a 7-minute, 3-person group conversation, using their prepared notes. Complete rubric (see Appendix C) while listening to conversation.

7. Provide feedback to Ss based on the feedback rubric. Ensure Ss take notes.

8. Two Ss leave, two arrive.

9. Again on the same topic, have Ss engage in a 7-minute, 3-person group conversation, using their prepared notes.

10. Provide feedback to Ss once more and have them make notes. Explain the homework preparation for next week's lesson. 


\section{Appendix C}

Textbook Lesson Two

POWER-UP DIALOGUE (Amrein et al., 2017)

\section{Asking for Help}

When we use English, sometimes we won't understand each other. That's OK! When we need help, it's always best to ask.

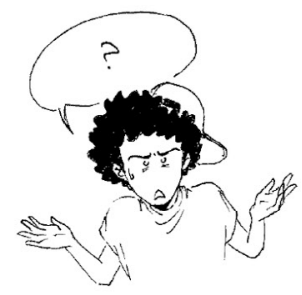

LESSON GOAL

What do I want to work on today?<smiles>[CH]C</smiles>

\section{REVIEW - MEET AND GREET}

Write your own introduction questions below.

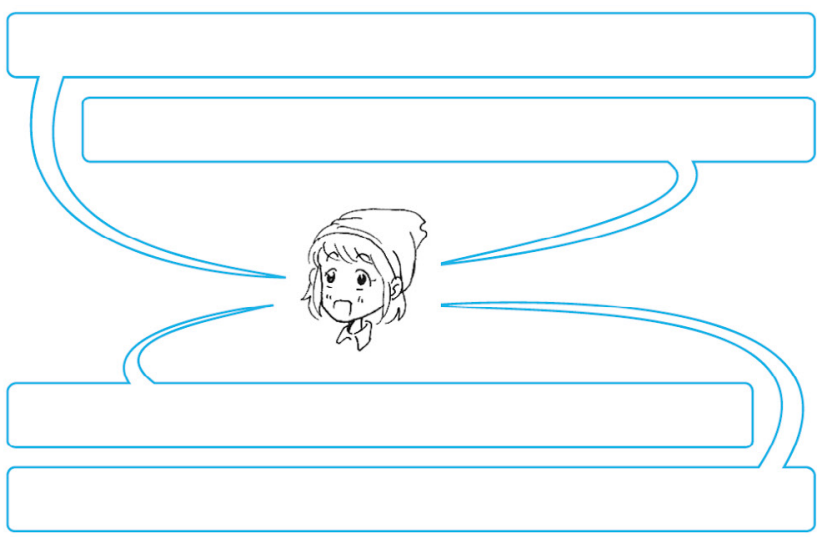

Use your questions to get to know your partner.

\section{WHEN YOU CAN'T HEAR}

Sometimes we may not hear each other clearly. If we need the speaker to repeat what he or she just said, we can just say:
didn't catch that.
Can you say that again?
Pardon?

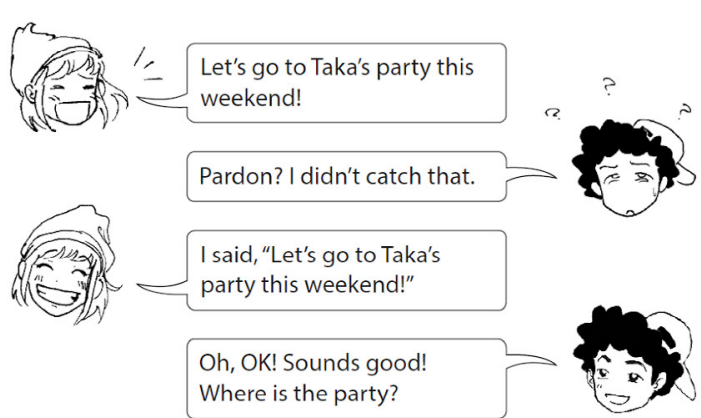

Say That Aqain: Write your ideas for a place or event to visit with a friend below.

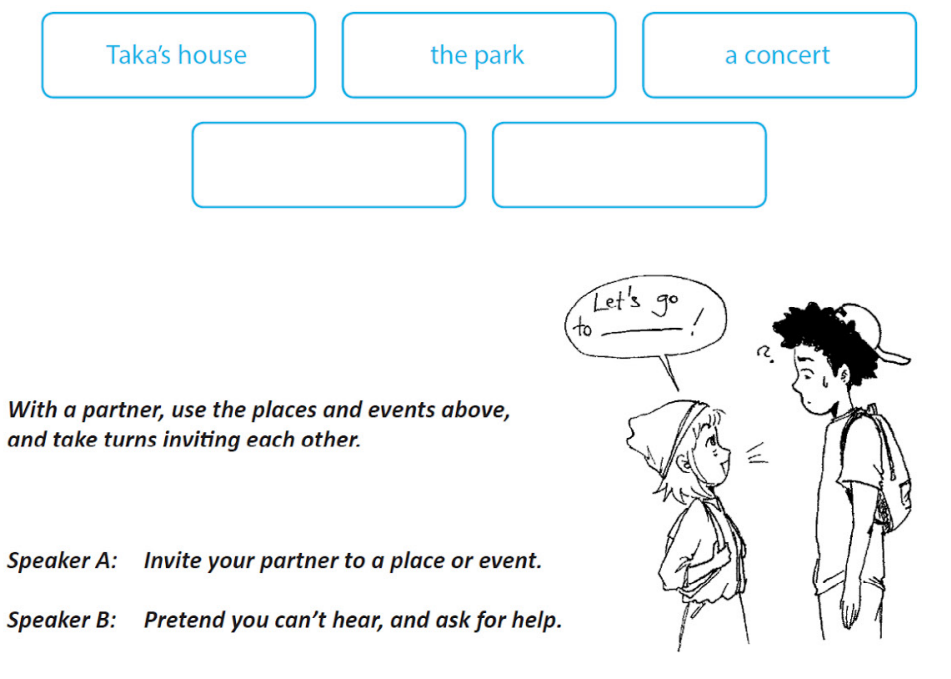




\section{WHEN YOU DON'T UNDERSTAND}

Sometimes we don't understand a difficult word or sentence. When we don't understand, we should ask for help:

What does that mean?

I don't follow.

I don't understand.

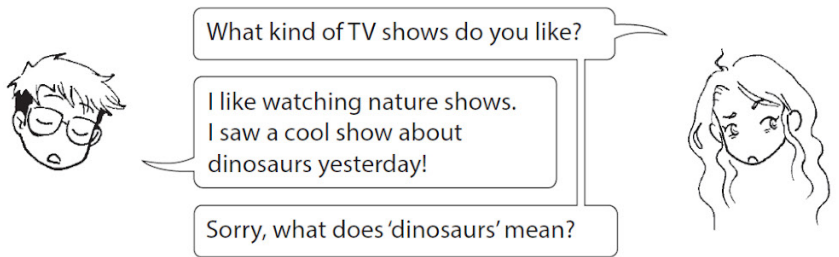

\section{CHECK FOR UNDERSTANDING!}

After helping someone, we should always make sure he or she understands:
Does that make sense?
Do you know what I mean?
Do you understand?

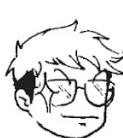

$$
\begin{aligned}
& \text { A dinosaur is a really big } \\
& \text { lizard. Like a T-Rex! } \\
& \text { Does that make sense? }
\end{aligned}
$$

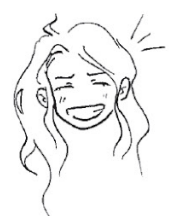

Help Each Other Understand: Practice both dialogues above with a partner. Replace "dinosaurs" with a different word. Use different phrases to ask for help and check for understanding.

\section{ROLE PLAY}

Taka and Charlie are talking about their
Taka doesn't understand a new word.

A: Tell Taka about your hobbies.

B: Pretend you don't understand, and ask for help.

A: Help Taka understand, and check for understanding.

\section{LET'S TALK - INTRODUCTIONS}

Now we will have an open discussion about ourselves. We can talk about things such as our hometown, family, school, hobbies, etc.

Use today's skill, and remember your Lesson Goal!

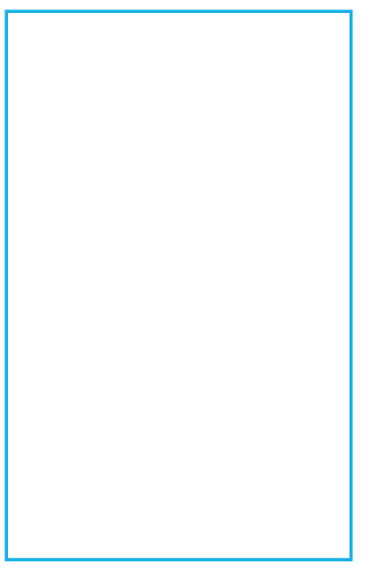

\section{LESSON REFLECTION}

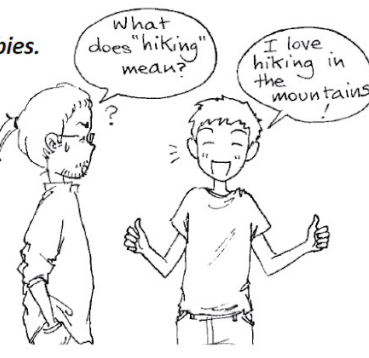

do Think about how you did today. Write down your feelings below.
Yo What went well? What would you like to improve next time? 


\section{Appendix D}

Semistructured Interview Questions

Note. Interviews conducted in Japanese and English.

1. How are you doing?

2. How is $[\mathrm{XXX}]$ life? $(* 1)$

3. How about $[\mathrm{XXX}]$ ? (*2)

4. What is your image of a good conversation?

(a) Where does it come from?

5. How do you know when you 've had a good conversation?

6. What do you do after you receive feedback from the teacher?

7. What do you think about changing partners and then continuing the topic?

8. Do you notice any changes in your speech between the conversations?

9. Do you think that your conversational ability has improved during this semester? (a) How can you tell?

10. Is there anything else that you want to talk about?

*1: University name. Omitted to protect anonymity.

*2: Course name. Omitted to protect anonymity. 